\title{
Correlation and Path Coefficient Analysis for Seed Yield and Agronomic Traits of Newly Introduced Pigeon Pea Genotypes in South Africa
}

\author{
A. Chisa ${ }^{1}$, P. Mafongoya ${ }^{1}$, A. O. Odindo ${ }^{1}$, M. M. Phophi ${ }^{1} \&$ S. E. Mwale ${ }^{1}$ \\ ${ }^{1}$ School of Agricultural, Earth and Environmental Sciences, University of KwaZulu-Natal, Pietermaritzburg, \\ South Africa \\ Correspondence: M. M. Phophi, School of Agricultural, Earth and Environmental Sciences, University of \\ KwaZulu-Natal, Pietermaritzburg, South Africa. E-mail: mutondiwa@gmail.com
}

Received: July 5, 2021

Accepted: August 17, $2021 \quad$ Online Published: October 15, 2021

doi:10.5539/jas.v13n11p33

URL: https://doi.org/10.5539/jas.v13n11p33

\begin{abstract}
Pigeon pea is an important source of protein for smallholder farmers in South Africa. The average seed yield per hectare ranges from 0.5 to 1 tonne due to the use of un-improved varieties that succumb to both biotic and abiotic stresses. Understanding the relationship between seed yield and agronomic traits in a genetically diverse germplasm collection is a prerequisite for developing an efficient selection and breeding program. This study determined the relationship between seed yield and agronomic traits to identify key traits for selection. Two separate experiments involving seven short and six medium duration pigeon pea genotypes were planted in a randomized complete block design (RCBD), each with three replications. Agronomic traits, including yield and its components' genotype mean data was subjected to correlation, path coefficient and stepwise regression analyses. The results showed a strong positive and significant correlation between number of pods per plant and seed yield in both medium and short duration genotypes. The number of pods per plant had a high direct effect on seed yield in both medium and short duration with values of $(0.43)$ and $(0.63)$ respectively. Number of branches and pod length exhibited high direct effect $(0.30-0.99)$ for medium duration. However, seed yield per plant was an important predictor of seed yield in short duration while seed yield per plant, 100 seed weight and number of seeds per pod were key predictors of seed yield in medium duration genotypes. Therefore, these traits should be targeted for seed yield improvement in Pigeon pea.
\end{abstract}

Keywords: crop improvement, direct effect, ICRISAT, legumes, plant breeding

\section{Introduction}

Pigeon pea [Cajanus cajun (L.) Mills sp.] is a multipurpose leguminous crop cultivated in the tropics and sub-tropics of Asia, Latin America and Africa. In South Africa, pigeon pea is an important source of income and nutrition to smallholder farmers. The crop has $20.5 \%$ crude protein which is available in the whole seed, although there are high-protein genotypes specially bred with up to $30 \%$ protein (Changaya, 2010). Despite its nutritional benefits, the average seed yield production in a South African farmer's field ranges from 0.5 to 1 tonne per hectare lower than those attained by most pigeon pea growing regions in sub-Saharan Africa (SSA) (Gwata \& Shimelis, 2013). The lower yield production is attributed to the use of un-improved landraces that succumb to both biotic and abiotic stresses (Hluyako et al., 2017).

Tremendous milestones in Pigeon pea crop improvement have been attained in other countries with the help of the International Crop Research Institute for the Semi-Arid Tropics (ICRISAT). For instance, specific agronomic traits for Pigeon pea yield improvement have been identified in Kenya and India (Cheboi et al., 2016). Since yield is a quantitative trait that results from an interplay of several inter-related traits and highly influenced by the environment with a low heritability (Rao et al., 2013). Selection based on seed yield alone is less efficient for improving Pigeon pea productivity. Nonetheless, selection efficiency for yield improvement can be attained by exploiting the interrelationships between yield and its associated traits. Correlation and path coefficient analyses are important in unravelling the relationships between key traits and designing effective breeding strategies for yield improvement (Rao et al., 2013; Kesha et al., 2014). However, their estimates are moderated by the environment and type of genotypes used (Kiranmai et al., 2016). Several studies in other countries have utilized 
correlation and path analyses to identify traits for selection in pigeon pea breeding programmes (Narayanan, Manivannan, \& Mahalingam, 2018; Zavinon et al., 2019; Nyirenda et al., 2020; Behera et al., 2020). Such studies, however, are limited in South Africa especially for the recently received short and medium duration Pigeon pea genotypes from ICRISAT, Kenya. Understanding the nature, magnitude, direction and strength of the relationship between yield and its components in these newly introduced Pigeon pea genotypes is key to improving selection efficiency and productivity. The adaptability of these uniquely bred pigeon pea genotypes across different agro-ecological zones in South Africa remains un-exploited. This study, therefore, was undertaken to determine the relationship between seed yield and agronomic traits in newly introduced pigeon pea genotypes under rain-fed conditions in KwaZulu-Natal, South Africa.

\section{Materials and Methods}

\subsection{Description of Experimental Site}

The study was conducted at the University of KwaZulu-Natal Ukulinga Research Farm, Pietermaritzburg, South Africa with latitude $29.66^{\circ} \mathrm{S}$, longitude $30.41^{\circ} \mathrm{E}$, and $775 \mathrm{~m}$ altitude (Mengistu et al., 2016). The study was conducted during 2018/2019 growing season under rainfed conditions. The Ukulinga Research Farm receives mean rainfall of $750 \mathrm{~mm} / \mathrm{year}$. The location has warm air temperatures during the months of December, January, February, and March with average temperatures of $26^{\circ} \mathrm{C}$. Mean temperatures are lower $\left(8{ }^{\circ} \mathrm{C}\right)$ in the months of June, July and August (Figure 1).

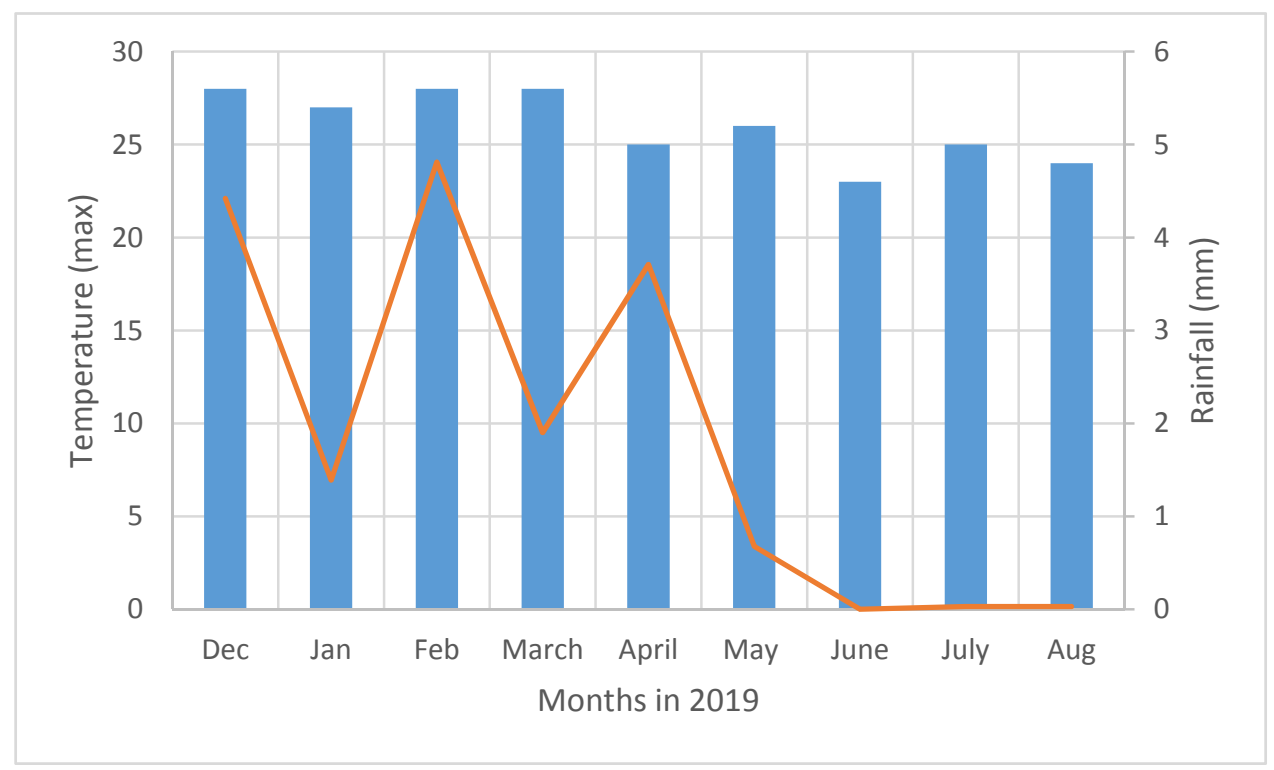

Figure 1. Monthly rainfall (mm) and temperature $\left({ }^{\circ} \mathrm{C}\right)$ from December 2018 to August 2019 in Ukulinga Research Farm Source: University of Kwazulu-Natal agro meteorology weather station mast

\subsection{Plant Genetic Materials}

The pigeon pea genotypes used in this study are presented in Table 1. The germplasm comprised of six medium and seven short duration pigeon pea genotypes from International Crops Research Institute for the Semi-Arid Tropics (ICRISAT), Kenya, selected for their unique yield characteristics. 
Table 1. Short and medium duration pigeon pea genotypes from ICRISAT

\begin{tabular}{ll}
\hline Short Duration & Medium Duration \\
\hline ICPL 87091 & ICEAP 00540 \\
ICPL 86012 & ICEAP 00557 \\
ICEAP 00660/3 & CEAP 00902 \\
ICEAP 01284 & ICEAP 00911 \\
ICEAP 01130/3 & ICEAP 00850 \\
ICEAP 00612 & ICEAP 00068 \\
ICEAP 01107/1 & \\
\hline
\end{tabular}

\subsection{Experimental Design}

The short and medium duration pigeon pea genotypes were planted in two separate experiments arranged in a Randomized Complete Block Design (RCBD) with three replications. Each short duration genotype was planted in a single row plot. Each row was $2.5 \mathrm{~m}$ long and $2 \mathrm{~m}$ wide, giving a plot size of $5 \mathrm{~m}^{2}$. Seeds were planted at 0.5 $\mathrm{m}$ apart within the row. Each medium duration genotype was planted in a single row plot. Each row was $3 \mathrm{~m}$ long and $2.5 \mathrm{~m}$ wide, giving a plot size of $7.5 \mathrm{~m}^{2}$. Seeds were planted at $0.3 \mathrm{~m}$ apart within the row.

\subsection{Agronomic Practices and Experimental Management}

Two seeds of pigeon pea genotypes were planted and later thinned to one plant two weeks after germination. Experimental plots were weeded when required using a hand hoe. No fertilizer was applied to the pigeon pea. Pests such as pod borers (Maruca testulalis and Helicoverpa armigera), pod suckers (Riptortus dentipes and Clavigralla sp.), and pod flies (Melanagromyza obtusa) were managed by applying cypermethrin, a broadspectrum pesticide. The pesticide was applied uniformly by using a 20-L knapsack sprayer.

\subsection{Data Collection}

Six sample plants were randomly selected and marked from each plot per genotype for data collection throughout the entire experiment. The following traits such plant height (measured in centimetres at harvest time), and number of branches were collected bi-weekly. Days to $50 \%$ flowering, days to $75 \%$ maturity, number of pods per plant, number of seeds per pod, pod length (measured in centimetres using a ruler), 100 seed weight, and seed yield per plant were determined from each plot according to the pigeon pea International Board for Plant Genetic Resources (IBPGR) guide (IBPGR and ICRISAT 1993). Environmental data such as rainfall and temperature were continuously monitored and recorded by UKZN Agrometeorology weather station mast.

\subsection{Data Analysis}

Agronomic traits, yield and yield components genotype mean data was subjected to correlation analysis in GenStat software $18^{\text {th }}$ edition (VSN International Ltd., Hertfordshire, United Kingdom) while path coefficient analysis was done in Microsoft Excel package as suggested by Dewey and Lu (1959). Path analysis was performed using a genotypic matrix which was set up as $\mathrm{A}=\mathrm{B} \times \mathrm{C}$ for seed yield, where, "A" represents the genotypic correlation coefficients of seed yield vs other agronomic traits in the matrix vector. Matrix vector "B" is the value of genotypic correlation for all possible combinations among the traits and vector $\mathrm{C}$ is the path coefficients. The inverse of matrix B was calculated using the Matrix Inverse function (MINVERSE) of Microsoft Excel 2016. The path coefficients were calculated as the product of vector A and each row of $\mathrm{B}^{-1}$ using the matrix multiplication (MMULT) function of Microsoft Excel 2016. Direct and indirect path coefficients were calculated according to Dewey and Lu (1959). Seed yield was regarded as the response variable, whereas other traits were causal variables. Path coefficients were classified as suggested by Lenka and Mishra (1973), where 0.00-0.09 is negligible association effects, $0.10-0.19$ is low, $0.20-0.29$ is moderate, $0.30-0.99$ is high and $>1.0$ is very high. The significance tests at $5 \%$ and $1 \%$ for the correlation coefficients of seed yield and other yield related traits was determined using a student's t-test (Snedecor \& Cochran, 1989). A stepwise regression analysis was employed to identify key first order predictors of seed yield in Statistical Product and Service Solutions (SPSS) version 25 (SPSS Inc., Chicago, IL, USA). Tolerance (TOL) and variance inflation factor (VIF) were utilized to measure the level of multi-collinearity for each predictor trait. A VIF of greater than five indicated high multicollinearity (Akinwande et al., 2015). 


\section{Results}

\subsection{Phenotypic Correlation of Seed Yield and Agronomic Traits of Short and Medium Duration Genotypes}

The correlation analysis results for seed yield and agronomic traits are presented in Table 2 and Table 3. In the short duration genotypes (Table 2), seed yield showed a strong positive significant correlation with number of pods per plant $(r=0.86 ; P<0.01)$ and plant height $(r=0.66 ; P<0.01)$. Seed yield exhibited a moderate positive significant correlation with 100 seed weight $(r=0.47 ; P<0.05)$ and number of branches $(r=0.38 ; P<0.05)$. In medium duration pigeon pea (Table 3), seed yield showed a strong positive significant correlation with days to $50 \%$ flowering $(r=0.71 ; P<0.001)$, days to maturity $(r=0.73 ; P<0.001)$, number of pods per plant $(r=0.72$; $P<0.001)$, pod length $(r=0.75 ; P<0.001)$, and number of branches $(r=0.81 ; P<0.001)$. Seed yield showed a moderate positive significant correlation with 100 seed weight $(r=0.48 ; P<0.05)$.

Table 2. Phenotypic correlation coefficients of traits that contribute to yield in short duration pigeon pea genotype

\begin{tabular}{llllllllll}
\hline Trait & Yield/Plant & $50 \%$ DTF & $75 \%$ DTM & PH & 100 SW & POD L. & NSP & NPP & Branches \\
\hline Yield/Plant & 1 & & & & & & & & \\
$50 \%$ DTF & $-0.21^{\text {ns }}$ & 1 & & & & & & & \\
$75 \%$ DTM & $-0.02^{\text {ns }}$ & $0.69^{\text {ns }}$ & 1 & & & & & & \\
PH & $0.66^{*}$ & $-0.21^{\text {ns }}$ & $-0.18^{\text {ns }}$ & 1 & & & & & \\
100 SW & $0.47^{*}$ & $0.00^{\text {ns }}$ & $0.14^{\text {ns }}$ & $0.14^{\text {ns }}$ & 1 & & & & \\
POD L. & $0.36^{\text {ns }}$ & $-0.16^{\text {ns }}$ & $-0.04^{\text {ns }}$ & $-0.25^{\text {ns }}$ & $0.34^{\text {ns }}$ & 1 & & & \\
NSP & $0.04^{\text {ns }}$ & $0.22^{\text {ns }}$ & $0.35^{\text {ns }}$ & $-0.22^{\text {ns }}$ & $-0.16^{\text {ns }}$ & $0.02^{\text {ns }}$ & 1 & & \\
NPP & $0.86^{*}$ & $-0.1^{\text {ns }}$ & $0.16^{\text {ns }}$ & $0.56^{\text {ns }}$ & $0.47^{\text {ns }}$ & $0.27^{\text {ns }}$ & $0.25^{\text {ns }}$ & 1 & \\
Branches & $0.38^{*}$ & $0.03^{\text {ns }}$ & $0.00^{\text {ns }}$ & $0.08^{\text {ns }}$ & $0.45^{\text {ns }}$ & $0.39^{\text {ns }}$ & $0.29^{\text {ns }}$ & $0.23^{\text {ns }}$ & 1
\end{tabular}

Note. DTF $=50 \%$ Days to Flowering; DTM $=75 \%$ Days to Maturity; NSP $=$ Number of Seeds per Pod; $100 \mathrm{SW}$ $=100$ Seed Weight $(\mathrm{g}) ; \mathrm{NPP}=$ Number of Pods per Plant; POD L. $=$ Pod Length, PH $=$ Plant Height.

* $=$ Significant at $\mathrm{P} \leq 0.05 ;{ }^{\mathrm{ns}}=$ Non-significant.

Table 3. Phenotypic correlations coefficients of traits that contribute to yield in medium duration pigeon pea genotypes

\begin{tabular}{l|lllllllll}
\hline Trait & Yield/Plant & $50 \%$ DTF & $75 \%$ DTM & PH & NPP & POD L. & 100 SW & NSP & Branches \\
\hline Yield/Plant & 1 & & & & & & & & \\
$50 \%$ DTF & $0.72^{*}$ & 1 & & & & & & & \\
$75 \%$ DTM & $0.73^{*}$ & $0.99^{*}$ & 1 & & & & & & \\
PH & $0.34^{\text {ns }}$ & $-0.09^{\text {ns }}$ & $-0.09^{\text {ns }}$ & 1 & & & & & \\
NPP & $0.72^{*}$ & $0.86^{*}$ & $0.88^{*}$ & $0.11^{\text {ns }}$ & 1 & & & & \\
POD L. & $0.75^{*}$ & $0.55^{*}$ & $0.61^{*}$ & $0.10^{\text {ns }}$ & $0.49^{\text {ns }}$ & 1 & & & \\
100 SW & $0.48^{*}$ & $0.33^{\text {ns }}$ & $0.36^{\text {ns }}$ & $0.12^{\text {ns }}$ & $0.35^{\text {ns }}$ & $0.83^{*}$ & 1 & & \\
NSP & 0.23 & $0.14^{\text {ns }}$ & $0.26^{\text {ns }}$ & $-0.17^{\text {ns }}$ & $0.15^{\text {ns }}$ & $0.46^{\text {ns }}$ & $0.19^{\text {ns }}$ & 1 & \\
Branches & $0.81^{*}$ & $0.36^{\text {ns }}$ & $0.34^{\text {ns }}$ & $0.75^{*}$ & $0.40^{\text {ns }}$ & $0.52^{*}$ & $0.35^{\text {ns }}$ & $0.02^{\text {ns }}$ & 1 \\
\hline
\end{tabular}

Note. $\mathrm{DTF}=50 \%$ Days to Flowering; DTM $=75 \%$ Days to Maturity; NSP $=$ Number of Seeds per Pod; $100 \mathrm{SW}$

$=100$ Seed Weight $(\mathrm{g})$; NPP $=$ Number of Pods per Plant; POD L. $=$ Pod Length, PH $=$ Plant Height.

$*=$ Significant at $\mathrm{P} \leq 0.05 ;{ }^{\text {ns }}=$ Non-significant.

\subsection{Path Coefficient Analysis of Seed Yield and Agronomic Traits of Short and Medium Duration Genotypes}

Path coefficients were classified as suggested by Lenka and Mishra (1973), where, 0.00-0.09 is negligible association effects, $0.10-0.19$ is low, $0.20-0.29$ is moderate, $0.30-0.99$ is high and $>1.0$ is very high. In short duration pigeon pea genotypes (Table 4), number of pods per plant exhibited high positive direct effect on seed yield $(0.60)$, followed by plant height $(0.36)$ and pod length $(0.25)$. The branches had a low direct effect on seed yield (0.13). Days to $50 \%$ flowering, days to $75 \%$ physiological maturity, 100 seed weight and the number of seeds per pod had negligible effect on the seed yield. 
Table 4. Genotypic path coefficient analysis direct effects on main diagonal (bold \& diagonal) and indirect effects (off diagonal) of different agronomic traits on seed yield of short duration pigeon pea

\begin{tabular}{llllllllll}
\hline Trait & $50 \%$ DTF & $75 \%$ DTM & Ph & $100 \mathrm{SW}$ & POD L. & NSP & NPP & Branches & $\begin{array}{l}\text { Correlations with } \\
\text { Yield/Plant }\end{array}$ \\
\hline $50 \%$ DTF & $\mathbf{0 . 0 5}$ & -0.03 & -0.08 & 0 & -0.04 & -0.01 & -0.1 & 0 & $-0.21 \mathrm{~ns}$ \\
$75 \%$ DTM & 0.03 & $\mathbf{- 0 . 0 4}$ & -0.07 & 0 & -0.01 & -0.02 & 0.1 & 0 & $-0.02 \mathrm{~ns}$ \\
PH & -0.01 & 0.01 & $\mathbf{0 . 3 6}$ & 0 & -0.06 & 0.01 & 0.34 & 0.01 & $0.66^{*}$ \\
100SW & 0 & -0.01 & 0.05 & $\mathbf{- 0 . 0 2}$ & 0.08 & 0.01 & 0.28 & 0.06 & $0.47^{*}$ \\
POD L. & -0.01 & 0 & -0.09 & -0.01 & $\mathbf{0 . 2 5}$ & 0 & 0.16 & 0.05 & $0.36 \mathrm{~ns}$ \\
NSP & 0.01 & -0.01 & -0.08 & 0 & 0 & $\mathbf{- 0 . 0 7}$ & 0.15 & 0.04 & $0.04 \mathrm{~ns}$ \\
NPP & -0.01 & -0.01 & 0.2 & -0.01 & 0.07 & -0.02 & $\mathbf{0 . 6}$ & 0.03 & $0.86^{*}$ \\
Branches & 0 & 0 & 0.03 & -0.01 & 0.1 & -0.02 & 0.15 & $\mathbf{0 . 1 3}$ & $0.38^{*}$ \\
\hline
\end{tabular}

Note. DTF $=50 \%$ Days to Flowering; DTM $=75 \%$ Days to Maturity; NSP $=$ Number of Seeds per Pod; $100 \mathrm{SW}$ $=100$ Seed Weight $(\mathrm{g}) ; \mathrm{NPP}=$ Number of Pods per Plant; POD L. $=$ Pod Length, PH $=$ Plant Height.

$*=$ Significant at $\mathrm{P} \leq 0.05 ;{ }^{\text {ns }}=$ Non-significant.

Table 5. Genotypic path coefficient analysis direct effects on main diagonal (bold \& diagonal) and indirect effects (off diagonal) of different agronomic traits on seed yield of medium duration pigeon pea

\begin{tabular}{llllllllll}
\hline Trait & \%50 DTF & 75\% DTM & PH & NPP & POD L. & 100 SW & NSP & Branches & $\begin{array}{c}\text { Correlation with } \\
\text { Seed Yield/Plant }\end{array}$ \\
\hline 50\% DTF & $\mathbf{0 . 1 8}$ & -0.3 & 0.03 & 0.37 & 0.24 & -0.07 & 0 & 0.27 & $0.72^{*}$ \\
$75 \%$ DTM & 0.18 & $\mathbf{- 0 . 3 1}$ & 0.03 & 0.38 & 0.27 & -0.08 & 0 & 0.26 & $0.73^{*}$ \\
PH & -0.02 & 0.03 & $\mathbf{- 0 . 3}$ & 0.05 & 0.04 & -0.03 & 0 & 0.56 & $0.34^{\mathrm{ns}}$ \\
NPP & 0.16 & -0.27 & -0.03 & $\mathbf{0 . 4 3}$ & 0.22 & -0.07 & 0 & 0.17 & $0.72^{*}$ \\
POD L. & 0.1 & -0.19 & -0.03 & 0.21 & $\mathbf{0 . 4 4}$ & -0.18 & 0 & 0.39 & $0.75^{*}$ \\
100 SW & 0.06 & -0.11 & -0.04 & 0.15 & 0.37 & $\mathbf{- 0 . 2 1}$ & 0 & 0.27 & $0.48^{*}$ \\
NSP & 0.03 & -0.08 & 0.05 & 0.06 & 0.21 & -0.04 & $\mathbf{- 0 . 0 1}$ & 0.01 & $0.23^{\text {ns }}$ \\
Branches & 0.07 & -0.11 & -0.23 & 0.17 & 0.23 & -0.08 & 0.01 & $\mathbf{0 . 7 5}$ & $0.81^{*}$ \\
\hline
\end{tabular}

Note. DTF $=50 \%$ Days to Flowering; DTM $=75 \%$ Days to Maturity; NSP $=$ Number of Seeds per Pod; $100 \mathrm{SW}$

$=100$ Seed Weight (g); NPP = Number of Pods per Plant; POD L. = Pod Length, PH = Plant Height.

* = Significant at $\mathrm{P} \leq 0.05 ;{ }^{\mathrm{ns}}=$ Non-significant.

For the medium duration genotypes, the number of branches had the highest positive direct effect on seed yield $(0.75)$ (Table 5). The genotypic path analysis also showed that number of pods per plant and pod length had high positive direct effect on seed yield of 0.43 and 0.44 , respectively. Days to $75 \%$ physiological maturity and days to $50 \%$ flowering exhibited a high negative direct effect to seed yield of 0.30 and 0.31 respectively. However, when subjected to a step wise regression analysis that isolates multicollinear traits, seed yield per plant was an important predictor of seed yield in short duration while Seed yield per plant, 100 seed weight and number of seeds per pod were key predictors of seed yield in medium duration genotypes (Tables 6 and 7).

Table 6. Relationship between seed yield and first order predictors in short-duration pigeon pea genotypes

\begin{tabular}{llllllll}
\hline Response Trait & Predictor trait & Standardized B & $\mathrm{t}$ & Significance & Adjusted R2 & Tolerance & VIF \\
\hline Seed Yield & Seed yield per plant & 0.95 & 10.87 & 0.001 & 91 & 1.00 & 1.00 \\
\hline
\end{tabular}

Note. VIF $=$ Variance inflation factor, $\mathrm{t}=\mathrm{t}$-Calculated, $\mathrm{Tol}=$ Tolerance. 
Table 7. Relationship between seed yield and first order predictors in medium-duration pigeon pea genotypes

\begin{tabular}{llllllll}
\hline Response Trait & Predictor trait & Standardized B & $\mathrm{t}$ & Significance & Adjusted R2 & Tolerance & VIF \\
\hline \multirow{3}{*}{ Seed Yield } & Seed yield per plant & 1.32 & 10.9 & 0.001 & 96 & 0.29 & 3.45 \\
& Number of seeds/pods & 0.19 & 4.49 & 0.002 & 98 & 0.73 & 1.37 \\
& 100 seed weight & -0.36 & -2.92 & 0.02 & 99 & 0.28 & 3.57 \\
\hline
\end{tabular}

Note. $\mathrm{VIF}=$ Variance inflation factor, $\mathrm{t}=\mathrm{t}$-Calculated, $\mathrm{Tol}=$ Tolerance.

\section{Discussion}

Seed yield is a culmination of its seed yield components, agronomic and environmental factors and their interaction. As such, understanding the nature of the relationship that exists among key traits is essential for designing efficient and effective selection and crop improvement programs (Mashilo, Shimelis and Odindo, 2016). In the short duration genotypes, the number of pods per plant $(r=0.86 ; P<0.001)$ and plant height $(r=$ $0.66 ; P<0.01)$ exhibited a strong positive significant correlation to seed yield. Implying the possibility of utilizing simultaneous selection for these traits to improve seed yield in short duration genotypes though testing at different agro-ecological zones is required to ascertain their usefulness. Similar results were reported by Khakhi (2014), and Nyirenda et al. (2020). Traits such as number of branches per plant $(r=0.38 ; P<0.05)$ and seed weight $(r=0.47 ; P<0.05)$ showed a moderate significant positive correlation with seed yield per plant. Studies by Thanki and Sawargaonkar (2010), Rao et al. (2013), and Kesha et al. (2014) reported similar findings. Days to $50 \%$ flowering, days to $75 \%$ maturity, pod length and number of seeds per pod traits were not significant in short duration genotypes contrary to Cheboi et al. (2016) findings. This could possibly be due to differences in genotypes used and testing environment conditions.

The medium duration genotypes exhibited a strong positive significant correlation between seed yield and number of days to physiological maturity $(r=0.73 ; P<0.001)$, number of branches per plant $(r=0.81 ; P<$ $0.001)$, days to flowering $(r=0.71 ; P<0.001)$, pods per plant $(r=0.72 ; P<0.001)$, pod length $(r=0.75 ; P<$ 0.001 ), implying simultaneous selection for these traits would result in increase in seed yield in medium duration genotypes, though more location testing is required to ascertain their usefulness and stability. There was a moderate correlation between 100 seed weight $(r=0.48 ; P<0.05)$ with seed yield. Kesha et al. (2014), Cheboi et al. (2016) and Narayanan et al. (2018) reported similar findings in pigeon pea crops. Days to $75 \%$ maturity showed positive and significant correlation with days to $50 \%$ flowering $(r=0.99, P<0.001)$. Further, number of pods per plant showed positive and significant correlation with days to flowering $(r=0.86 ; P<0.001)$ and days to maturity $(r=0.88 ; P<0.001)$. Implying selection for earliness can be based on number of pods per plant. The results correspond the findings of Prasad et al. (2013). Saxena et al. (2019) highlighted the importance of selecting for earliness in pigeon pea genotypes for increased productivity of the crop and production of protein-rich legumes to meet the nutritional needs of small-holder farming communities.

\subsection{Direct and Indirect Effects of Traits to Grain Yield}

In crop improvement studies, it is challenging to determine which traits contributed to the increase in seed yield when multiple variables are included in the correlation analysis. Path coefficient analysis is a technique that overcomes this challenge by partitioning associations; it examines the relative contribution of direct and indirect effects of each trait independently and its contribution to yield (Thanki \& Sawargaonkar, 2010; Kesha et al., 2014). In this study, the eight traits were considered as variables that determined seed yield.

Generally, number of pods per plant showed high and positive direct effect on seed yield for both medium (0.43) and short (0.60) duration genotypes. Thanki and Sawargaonkar (2010), Rao et al. (2013), Kesha et al. (2014) and Narayanan et al. (2018) reported similar findings of a high positive direct effect of number pods per plant. In medium duration genotypes there is relatively high and positive direct effect between $75 \%$ DTM to number of pods/plant (0.38), number of branches and pod length (0.56) and 50\% DTF to number of pods/plant (0.37). Mashilo et al. (2016) reported that simultaneous selection of two traits that have high direct effect of each other may improve yield. These traits can, therefore, be used for direct selection for seed yield improvement in pigeon pea genotypes, though more testing is required to account for the effect of the environment and season on the phenotypic expression of these traits. Additionally, selection in medium duration genotypes should target pod length and number of branches as these showed a high direct effect on seed yield of (0.44) and (0.75) respectively. In short duration genotypes it is equally important to consider plant height $(0.36)$, pod length $(0.25)$ as they had moderate to high effect on seed yield. 
Precise contribution of first order predictors such as number of pods per plant, seed yield per plant, 100 seed weight and number of seeds per pod to seed yield was explored further through a stepwise regression analysis, that automatically removes traits with negligible contribution to yield and/or with high multi-collinearity. Seed yield per plant was an important predictor of seed yield in short duration while Seed yield per plant, 100 seed weight and number of seeds per pod were key predictors of seed yield in medium duration genotypes. Implying that selection for seed yield improvement in Pigeon pea genotypes should target these traits.

\section{Conclusion}

The study determined that there was a relationship between seed yield and agronomic traits in short and medium pigeon pea genotypes. The path coefficient analysis results for medium duration pigeon pea genotypes revealed that number of branches, number of pods per plant and pod length were good seed yield contributors. While in short duration pigeon pea genotypes, number of pods per plant, plant height and the pod length contributed to increase in seed yield. However, for efficient selection for seed yield improvement in Pigeon pea, traits such as seed yield per plant in short duration genotypes and seed yield per plant, 100 seed weight and number of seeds per pod in medium duration genotypes should be emphasized with more multiple location testing.

\section{References}

Akinwande, M. O., Dikko, H. G., \& Samson, A. (2015).Variance Inflation Factor: As a Condition for the Inclusion of Suppressor Variable(s) in Regression Analysis. Open Journal of Statistics, 5, 754-767. https://doi.org/10.4236/ojs.2015.57075

Behera, S. K., Arvind, K. S., Pankaj, K. T., Ajay, T., Pooja, S., Vivek, T., ... Soumitr, D. (2020). Classification of Pigeonpea (Cajanus cajan (L.) Mill sp.) Genotypes for Zinc Efficiency. Plants, 9(8), 952. https://doi.org/ $10.3390 /$ plants9080952

Changaya, A. G. (2010) Development of high yielding pigeonpea (Cajanus cajan) germplasm with resistance to Fusarium wilt (Fusarium udum) in Malawi (Doctoral dissertation, University of KwaZulu-Natal, South Africa). Retrieved from https://researchspace.ukzn.ac.za/handle/10413/332

Cheboi, J. J., Kinyua, M. G., Kimurto, P. K., Kiplagat, O. K., Towett, B. K., Kirui, S. C., ... Gangarao, N. V. P. R. (2016). Yield Potential and Adaptability of Medium Duration Pigeonpea (Cajanus cajan L. Mill sp.) Genotypes in Dry Parts of North Rift Valley, Kenya. International Journal of Agronomy and Agricultural Research, 9(2), 47-56.

Gwata, E. T., \& Shimelis, H. (2013). Evaluation of Pigeonpea Germplasm for Important Agrnomic Traits in Southern Africa. In A. Goyal, \& M. Asif (Eds.), Crop Production (pp. 1-11). InTech. https://doi.org/ $10.5772 / 56094$

Hluyako, L. L., Odindo, A. O., Mafongoya, P., Sithole, N. J., \& Magwaza, L. S. (2017). Characterisation of Pigeon Pea (Cajanus cajan) Landraces Grown in Two Climatic Zones in KwaZulu-Natal Province, South Africa. South African Journal of Plant and Soil, 34(3), 191-199. https://doi.org/10.1080/02571862. 2016.1266044

IBPGR and ICRISAT. (1993). Descriptors for pigeonpea. International Crops Reseach Institute for the Seme-Arid Tropics, Patancheru, India.

Kesha, R., Saxena, K., Shrimali, T. M., \& Bisnoi, G. (2014). A Study on Genetic Variability and Correlation in Pigeon Pea [Cajanus cajan (L.) Mill sp.]. International Journal of Agriculture Sciences, 3(9), 2012-2014.

Khakhi, N. (2014) Evaluation of Malawi pigeon pea accessions for tolerance to moisture stress and superior agronomic traits in Uganda (Master's thesis, Makerere University, Uganda). Retrieved from http://makir.mak.ac.ug/handle/10570/3424

Kinfe, H., Alemayehu, G., Wolde, L., \& Tsehaye, L. (2015). Correlation and Path Coefficient Analysis of Grain Yield and Yield Related Traits in Maize (Zea mays L.) Hybrids, at Bako. Journal of Biology, Agriculture and Healthcare, 5(15), 44-53.

Kiranmai, M. S., Venkataravana, P., \& Pushpa, H. (2016).Correlation and path analysis studies in groundnut under different environment. Legum Research, 6(39),1048-1058. https://doi.org/10.18805/lr.v0iOF.4484

Mashilo, J., Shimelis, H., \& Odindo, A. O. (2016). Correlation and Path Coefficient Analyses of Qualitative and Quantitative Traits in Selected Bottle Gourd Landraces. Acta Agriculturae Scandinavica Section B: Soil and Plant Science, 66(7), 558-569. https://doi.org/10.1080/09064710.2016.1197965

Mengistu, M. G., Steyn, J. M., Kunz, R. P., Doidge, I., Hlophe, H. B., Everson, C. S., .. Clulow, A. D. (2016). A 
Preliminary Investigation of the Water Use Efficiency of Sweet Sorghum for Biofuel in South Africa. Water SA, 42(1), 152-160. https://doi.org/10.4314/wsa.v42i1.15

Narayanan, S. L., Manivannan, N., \& Mahalingam, A. (2018). Correlation And Path Analyses of Yield and Its Component Traits in Pigeonpea [Cajanus cajan (L.) Mill sp.]. International Journal of Current Microbiology and Applied Sciences, 7(03), 614-618. https://doi.org/10.20546/ijcmas.2018.703.073

Nyirenda, Y. E., Hussein, S., Mark, L., Isack, M., \& Admire, S. (2020). Phenotypic Divergence Analysis in Pigeonpea [Cajanus cajan (L.) Millspaugh] Germplasm Accessions. Agronomy, 10(11), 1682. https://doi.org/10.3390/agronomy10111682

Prasad, Y., Kumar, K., \& Mishra, B. K. (2013). Studies on genetic parameters and interrelationships among yield and yield contributing traits in pigeonpea [Cajanus cajan (L.) Mill sp.]. The Bioscan, 8(1), 23-27.

Rao, P. J. M., Malathi, S., Reddy, D. V. V., \& Upender, M. (2013). Genetic Studies of Association and Path Coefficient Analysis of Yield and its Component Traits in Pigeon Pea. International Journal of Scientific and Research Publications, 3(8), 1-5. Retrieved from http://www.ijsrp.org/research-paper-0813/ijsr 20101.pdf

Saxena, K., Choudhary, A. K., Srivastava, R. K., Bohra, A., Saxena, R. K., \& Varshney, R. K. (2019). Origin of Early Maturing Pigeonpea Germplasm and its Impact on Adaptation and Cropping Systems. Plant Breeding, 13(8), 243-251. https://doi.org/10.1111/pbr.12696

Silim, S. N., Ric, C., Omanga, P. A., \& Gwata, E. T. (2007). The response of pigeon pea genotypes of different duration types to variation in tempreture and photoperiod under field conditions in Kenya. Journal of Food, Agriculture \& Environmenet, 4(1), 209-214.

Thanki, H. P., \& Sawargaonkar, S. L. (2010). Path Coefficient Analysis in Pigeonpea (Cajanus cajan L. Millsp.). Electronic Journal of Plant Breeding, 1(4), 936-939.

Zavinon, F., Adoukonou-Sagbadja, H., Bossikponnon, A., Dossa, H., \& Ahanhanzo, C. (2019). Phenotypic diversity for agro-morphological traits in pigeon pea landraces [(Cajanus cajan L.) Mill sp.] cultivated in southern Benin. Open Agriculture, 4(1), 487-499. https://doi.org/10.1515/opag-2019-0046

\section{Copyrights}

Copyright for this article is retained by the author(s), with first publication rights granted to the journal.

This is an open-access article distributed under the terms and conditions of the Creative Commons Attribution license (http://creativecommons.org/licenses/by/4.0/). 